Research Article

\title{
The Role of Maternal Progesterone and Estradiol Levels in Predicting the Success of Induction of Labour : A Preliminary Study
}

\author{
Hubungan Kadar Progesteron dan Estradiol Ibu terhadap Keberhasilan \\ Induksi Persalinan : Suatu Studi Pendahuluan
}

\author{
Kanadi Sumapraja, Hilda R Badruddin \\ Department of Obstetrics and Gynecology \\ Faculty of Medicine Universitas Indonesia \\ Dr. Cipto Mangunkusumo General Hospital \\ Jakarta
}

\begin{abstract}
Objective : to evaluate whether maternal progesterone and estradiol levels could be used to predict the success of induction of labour (IOL).

Methods: This cross-sectional study was conducted at the Women's Health Clinic as well as the delivery suite of Dr. Cipto Mangunkusumo Hospital during the period of May 2016 to April 2017. Blood samples of term pregnant women who were indicated for IOL were obtained before birth.

Results: A total of 44 subjects were recruited in this study. Of these, 24 subjects had successful IOL while the other 20 subjects had IOL failure. There was no significant difference in progesterone among both groups $(66,7 \%$ vs $75 \%, p=0,55)$. The estradiol levels in subjects who successfully performed induction had an average of 16,916.28 $\pm 2,574.75 \mathrm{pg} / \mathrm{mL}$ which did not differ significantly from the failed of induction group with estradiol levels of $14,832.24 \pm 2374.47 \mathrm{pg} / \mathrm{mL}$ ( $\mathrm{p}$ $=0,65$ ).

Conclusions : We found no significant association between both maternal progesterone and estradiol levels and the success rate of IOL. Further studies with larger sample sizes are required to confirm whether progesterone and estradiol play pivotal roles in the success of IOL.
\end{abstract}

Keywords : estradiol, induction of labour, progesterone.

\begin{abstract}
Abstrak
Tujuan : mengevaluasi kadar progesteron dan estradiol ibu sebagai prediktor kesuksesan induksi persalinan.

Metode : Penelitian ini menggunakan desain potong lintang yang berlangsung pada bulan Mei 2016 hingga April 2017 di Poliklinik dan IGD Kebidanan Rumah Sakit Umum Pusat Rujukan Nasional Cipto Mangunkusumo. Pasien hamil aterm yang dilakukan induksi persalinan dan memenuhi kriteria penelitian akan diambil sampel darah sebelum persalinan.

Hasil : Dari 44 subjek yang mengikuti penelitian, 24 subjek berhasil dilakukan induksi persalinan dan 20 subjek gagal. Tidak terdapat perbedaan bermakna pada kadar progesteron Antara kedua grup $(66,7 \%$ vs $75 \%, p=0,55)$. Kadar estradiol pada pasien yang berhasil dilakukan induksi memiliki ratarata $16.916,28+2.574,75 \mathrm{pg} / \mathrm{mL}$ yang tidak berbeda jauh dengan kadar estradiol pasien yang gagal induksi yaitu $14.832,24+2374,47 \mathrm{pg} / \mathrm{mL}(\mathrm{p}=0,65)$.
\end{abstract}

Kesimpulan : Tidak terdapat perbedaan bermakna antara kadar progesteron dan estradiol maternal terhadap keberhasilan induksi persalinan. Penelitian lebih lanjut dengan jumlah sampel yang lebih besar dibutuhkan untuk mengkonfirmasi hubungan ini dengan lebih baik.

Kata kunci : estradiol, induksi persalinan, progesteron

Correspondence author : Kanadi Sumapraja, kanadisuma@yahoo.com

\section{INTRODUCTION}

Induction of labour (IOL) is one of the most common procedures in modern obstetrics, performed in approximately $20 \%$ of all deliveries ${ }^{1-3}$. Despite being frequently performed, IOL does not always result in vaginal delivery, particularly when the cervix is not ready for induction ${ }^{4,5}$. Therefore, it is important to determine the most appropriate method to predict successful IOL and vaginal delivery.
Previously, the traditional method to assess whether induced labour will result in successful vaginal delivery is the Bishop's score. However, Bishop's score is subjective, and it is not accurate for predicting the outcome of labour induction ${ }^{6-9}$, especially when the external ostium is closed ${ }^{6,10}$. In addition, the procedure of calculating Bishop's score is painful. By considering these limitations, the necessity of finding alternative measures to predict the success of IOL is obvious. 
Progesterone and estradiol are considered essential hormones in the process of parturition. At term, human parturition requires an orchestrated set of hormonal and morphological changes within uterine tissues ${ }^{11}$, some of which include up-regulation of myometrial progesterone $A$, estrogen $\alpha$, prostaglandin, and oxytocin receptors. A decreased progesterone/estradiol ratio has been associated with successful labour ${ }^{12}$.

To our knowledge, no studies regarding the role of progesterone and estradiol levels in predicting IOL successfulness have been conducted. We aimed to investigate whether maternal progesterone and estradiol could be used to predict the success of IOL.

\section{METHODS}

A cross-sectional study design was used. This study was conducted at Dr. Cipto Mangunkusumo Hospital, Jakarta, Indonesia, during the period between May 2016 and April 2017. Subjects were term pregnant women who were indicated to undergo IOL. Exclusion criteria were twin pregnancy and breech presentation. Maternal progesterone and estradiol levels were assessed immediately before birth in all subjects.

\section{Blood sampling}

Blood (5 mL) samples were collected by venipuncture of the brachial vein immediately before birth in all cases. Collected blood samples would be sent directly to a laboratory to assay serum analysis of progesterone and estradiol.

\section{Statistical analysis}

All statistical analysis was performed using SPSS 23 for Mac. Normally distributed continuous variables were compared using the Student's unpaired t-tests, while nonnormal distributed variables were compared using the MannWhitneyU test. For categorical variables, the Chi-Square or Fisher's exact test was carried out as appropriate. Pvalues less than 0.05 were considered statistically significant.

\section{RESULTS}

A total of 44 subjects were recruited in this study. Twenty-four subjects successfully induced labour, while 20 had induction failure. Maternal age, parity, and gestational age were similar among groups (Table 1). Statistical analysis revealed that cervical length and initial pelvic score differed among both groups $(p=0,02$ and $p<0,01$, respectively). We did not find significant difference between maternal progesterone and estradiol levels among both groups $(p=0,55$ and $p=0,65$, respectively) Types of induction, progesterone levels, estradiol levels, estimated fetal weight, amniotic fluid index, and the presence of anaemia, rupture of membranes, and severe preeclampsia were not significantly associated with the success of IOL.

Table 1. Baseline Maternal and Fetal Characteristics of the Subjects

\begin{tabular}{|c|c|c|c|c|}
\hline Characteristics & Induced labour $(n=24)$ * & Induced labour $(n=24)^{*}$ & $P$-value & OR (CI 95\%) \\
\hline Age (years) & $31.08+1.18$ & $28.35+1.13$ & $0.11^{\mathrm{D}}$ & \\
\hline \multicolumn{5}{|l|}{ Parity } \\
\hline Nulliparous & $12(50 \%)$ & 14 (70\%) & $0.18^{\mathrm{B}}$ & $0.429(0.12-1.49)$ \\
\hline Multiparous & $12(50 \%)$ & $6(30 \%)$ & & \\
\hline $\begin{array}{l}\text { Gestational age (weeks) } \\
\text { Methods of IOL }\end{array}$ & $38(37-41)$ & $37(37-41)$ & $0.54^{c}$ & \\
\hline Misoprostol & 22 (91.7\%) & 19 (95\%) & $1.000^{\mathrm{A}}$ & $0.58(0.49-6.99)$ \\
\hline $\begin{array}{l}\text { Other (Foley catheter } \\
\text { and oxytocin) }\end{array}$ & $2(8.3 \%)$ & $1(5 \%)$ & & \\
\hline Progesterone levels & & & & $0.67(0.18-2.50)$ \\
\hline$>60 \mathrm{ng} / \mathrm{mL}$ & 16 (66.7\%) & 15 (75\%) & $0.55^{\mathrm{A}}$ & \\
\hline$\leq 60 \mathrm{ng} / \mathrm{mL}$ & $8(33.3 \%)$ & $5(25 \%)$ & & 2084.03 (- 5097.28- \\
\hline Estradiol levels & $16.916 .28+2.574 .75$ & $14.832,24+2.374,47$ & $0.65^{\mathrm{D}}$ & 9265.35) \\
\hline $\begin{array}{l}\text { Estimated fetal weight } \\
\text { (grams) }\end{array}$ & $2890.17+98.76$ & $2813.15+109.98$ & $0.61^{\mathrm{D}}$ & \\
\hline Amniotic fluid index & $8.81(7-32)$ & $10(5-19)$ & $0.64^{c}$ & \\
\hline Cervical length (centimeters) & $2.82(1.8-3.56)$ & $3.09(1.8-3.49)$ & $0.02^{c}$ & \\
\hline Initial pelvic score & $2.5(0-7)$ & $1(0-4)$ & $<0,01^{c}$ & \\
\hline Anemia & 5 (20.8\%) & $6(30 \%)$ & $0.484^{B}$ & $0.61(0,16-2.42)$ \\
\hline Rupture of membranes & $17(70.8 \%)$ & $10(50 \%)$ & $0.16^{\mathrm{B}}$ & $0.41(0,12-1.43)$ \\
\hline Severe preeclampsia & $21(87.5 \%)$ & 16 (80\%) & $0.65^{\mathrm{A}}$ & $1.75(0.34-8.95)$ \\
\hline
\end{tabular}


${ }^{*}$ Categorical data are presented in frequency (percentage), while numerical data are presented in mean \pm SD

AUsing Fisher's exact test, BUsing Chi-Square test, 'Using Mann Whitney $U$ test, DUsing student's unpaired t-test

\section{DISCUSSION}

Several factors that affect the successfulness of IOL include maternal progesterone and estradiol levels, maternal age, gestational age, parity, body mass index, initial cervical dilatation, initial pelvic score, methods of IOL, amniotic fluid index, the presence of anemia, the presence of severe preeclampsia, doses of misoprostol, oxytocin, birthweight, and rupture of membranes ${ }^{12-14}$. In our study, we did not find significant association between maternal age, parity, gestational age, methods of IOL, estimated fetal weight, initial pelvic score, amniotic fluid index, anaemia, rupture of membranes, and severe preeclampsia, and the success of IOL. However, cervical length and initial pelvic score were significantly associated with IOL successfulness ( $p=0,02$ and $p<0,01$, respectively).

In the present study, we did not find a significant association between progesterone level and the successfulness of IOL. This is in line with a previous study by Konopka et $a{ }^{12}$ which reported that patients with high progesterone levels also achieved successful dinoprostone-induced labour. In viviparous species, progesterone withdrawal is a main trigger for parturition. In the majority of animals, parturition is preceded by a decrease in circulating progesterone levels mediated by hormonal interactions that inhibit progesterone production by either placenta or corpus luteum ${ }^{15}$. However, in human, parturition occurs without a decrease in systemic progesterone levels. Labour would still occur even if the myometrial cells are exposed to high levels of progesterone ${ }^{16-18}$. One possible explanation is that progesterone withdrawal in human parturition is partly mediated by changes in the relative levels of the nuclear progesterone isoforms, progesterone receptor- $A$ (PR-A) and progesterone receptor-B (PR-B), in myometrial cells. When PR-A expression is elevated, it inhibits the anti-inflammatory actions of PR-B and stimulates-inflammatory gene expression in response to progesterone, which may result in labour ${ }^{19}$.

Previous studies in women have found that one of the keys to initiation of parturition is local steroid hormone metabolism ${ }^{20}$. Estrogen, particularly estradiol, promotes labour by stimulating biochemical and physical changes in myometrial cells that affect uterine contractility and excitability. Numerous studies have suggested that estradiol increases the expression of genes in myometrium cells that promote synchronised contractions. In this study, although maternal estradiol level in the induced labour group was higher, it was not significantly associated with the success of IOL. This is in contrast to a previous study by Konopka et al ${ }^{12}$ which found that higher estradiol level was linearly associated with the success of dinoprostone-induced labour. In pregnancy, the myometrium is exposed to high levels of estrogen in the forms of estradiol, estrone, and estriol for the majority of pregnancy. Prior to labour onset, systemic estrogen levels remain roughly the same ${ }^{21}$. Despite the high levels of circulating progesterone and estrogen levels during pregnancy, the levels of estradiol could decrease. This might occur due to changes in $17 \beta$ hydroxysteroid dehydrogenase (17ßHSD) type 2.Cervical epithelium possessed high oxidative $17 \beta H S D$ activity by efficiently converting estradiol to estrone. Increased $17 \beta H S D$ type 2 expression in the cervical epithelia maintains elevated progesterone levels with a decrease in estradiol, similar to the steroid hormonal environment of the mouse cervix during the softening phase of remodelling. However, during parturition, $17 \beta$ HSD type 2 was down-regulated, thereby leading to increased estradiol levels ${ }^{21}$.

To this date, studies concerning the levels of estradiol prior to labour onset are scarce. We speculate the insignificant association between estradiol levels and the success of IOL is due to complex biomolecular interactions underlying the metabolism of estrogen and its receptors, particularly estrogen receptor (ER ) and estrogen receptor $\beta$ (ERß). Progesterone may inhibit ER $\alpha$ and $E R \beta$ expression, which may prevent labour ${ }^{22,23}$.

\section{CONCLUSION}

We find that both maternal progesterone and estradiol levels are not significantly associated with the success rate of IOL. Further studies with larger sample sizes are required to confirm whether progesterone and estradiol play pivotal roles in the success of IOL. 


\section{REFERENCES}

1. Martin JA, Hamilton BE, Sutton PD, Ventura SJ, Menacker F, Munson ML. Births: Final data for 2002. Natl Vital Stat Rep 2003;52:1-113.

2. Kehila M, Abouda HS, Sahbi K, Cheour H, Chanoufi MB. Ultrasound cervical length measurement in prediction of labor induction outcome. JNPM 2016;9:127-31.

3. Kang WS, Park KH, Kim SN, Shin DM, Hong JS, Jung HJ. The degree of cervical shortening after initial induction of labor as a predictor of subsequent successful induction. Ultrasound Obstet Gynecol 2010;36:749-54.

4. Nikbaht $R$, Hemadi M. Transvaginal cervical length and Bishop score value in predicting successful labor induction with an emphasis on the parity. IJPRAS 2016;5(2):114-8.

5. Cubal A, Carvalho J, Ferreira MJ, Rodrigues G, Carmo OD. Value of Bishop score and ultrasound cervical length measurement in the prediction of cesarean delivery. J Obstet Gynecol Res 2013;39:1391-6.

6. Friedman EA, Niswander $K R$, Bayonet-Rivera NP, Sachtleben MR. Relation of prelabour evaluation to inducibility and the course of labour. Obstet Gynecol 1966; 28:495-501.

7. Hughey MJ, McElin TW, Bird CC. An evaluation of preinduction scoring systems. Obstet Gynecol 1976;48:63541.

8. Dhall K, Mittal SC, Kumar A. Evaluation of pre-induction scoring systems. Aust N Z J Obstet Gynacol 1987;27:30911.

9. Hendrix NW, Chauhan SP, Morrison JC, Magann EF, Martin JN Jr., Devoe LD. Bishop score: A poor diagnostic test to predict failed induction versus vaginal delivery. South Med J 1998;91:248-52.

10. Roman $H$, Verspyck E, Vercoustre L, et al. Does ultrasound examination when the cervix is unfavorable improve the prediction of failed labor induction? Ultrasound Obstet Gynecol 2004;23:357-62.

11. Snegovskikh V, Park JS, Norwitz ER. Endocrinology of parturition. Endocrinol Metabol Clin North Am 2006; 35(1): 173-viii.

12. Konopka CK, Morais EN, Naidon D, et al. Maternal serum progesterone, estradiol, and estriol levels in successful dinoprostone-induced labor. Braz J Med Biol Res 2013;46(1):91-7.
13. Bahadori $F$, Ayatollahi $H$, Naghavi-Behzad M, Khalkhali $H$, Naseri Z. Predicting factors on cervical ripening and response to induction in women pregnant over 37 weeks. Med Ultrasound. 2013;15(3):191-8.

14. Wing DA, Tran S, Paul RH. Factors affecting the likelihood of successful induction after intravaginal misoprostol application for cervical ripening and labor induction. Am J Obstet Gynecol. 2002;186(6):1237-40; discussion 40-3.

15. Young IR, Renfree MB, Mesiano S, Shaw G, Jenkin G, Smith R. The comparative physiology of parturition in mammals: hormones and parturition in mammals. In: Norris D, Lopez K, editors., eds. Hormones and reproduction in vertebrates. London: Academic Press.2010;5:95-116.

16. Walsh SW, Stanczyk FZ, Novy MJ. Daily hormonal changes in the maternal, fetal, and amniotic fluid compartments before parturition in a primate species. J Clin Endocrinol Metabol 1984;58:629-39

17. Boroditsky RS, Reyes FI, Winter JS, Faiman C. Maternal serum estrogen and progesterone concentrations preceding normal labor. Obstet Gynecol,1978;51:68691

18. Tulchinsky D, Hobel CJ, Yeager E, Marshall JR. Plasma estrone, estradiol, estriol, progesterone, and 17hydroxyprogesterone in human pregnancy. I. Normal pregnancy. Am J Obstet Gynecol ,1972;112:1095-1100

19. Tan $H$, Yi L, Rote NS, Hurd WW, Mesiano S. Progesterone receptor- $A$ and $-B$ have opposite effects on proinflammatory gene expression in human myometrial cells: implications for progesterone actions in human pregnancy and parturition. J Clin Endocrinol Metabol 2012;97(5):E719-30.

20. Andersson S, Minjarez D, Yost NP, Word RA. Estrogen and progesterone metabolism in the cervix during pregnancy and parturition. J Clin Endocrinol Metabol 2008;93(6):2366-74.

21. Kota SK, gayatri K, Jammula $S$, et al. Endocrinology of parturition. Ind J Endocrinol Metabol, 2013;17(1):50-9.

22. Capece A, Vasieva O, Meher S, Alfirevic Z, Alfirevic A. Pathway analysis of genetic factors associated with spontaneous preterm birth and pre-labor preterm rupture of membranes. PLoS One. 2014;9(9):e108578.

23. Mesiano S, DeFranco E, Muglia LJ. Parturition. Knobil and Neill's Physiology of Reproduction. Fourth ed: Elsevier Inc.; 2015;2:1875-909. 